Proceedings

\title{
Threats and Challenges for Conservation of Meloidae (Coleoptera) in a Global Change Context, Emphasizing the Ibe- rian Peninsula ${ }^{\dagger}$
}

\section{Fernando Cortés-Fossati}

Citation: Cortés-Fossati, F. Hypermetabolous and highly diverse: threats and challenges for Meloidae conservation (Coleoptera, Insecta) in global change, in Proceedings of the 1st International Electronic Conference on Entomology, 1-15 July 2021, MDPI: Basel, Switzerland, doi:10.3390/IECE-10495

Published: 1 July 2021

Publisher's Note: MDPI stays neutral with regard to jurisdictional claims in published maps and institutional affiliations.

Copyright: (C) 2021 by the authors Submitted for possible open access publication under the terms and conditions of the Creative Commons Attribution (CC BY) license (http://creativecommons.org/licenses /by/4.0/).
Area of Biodiversity and Conservation, Universidad Rey Juan Carlos, c/Tulipán s/n., Móstoles, E-28933 Madrid, Spain; fernando.cfossati@urjc.es

† Presented at the 1st International Electronic Conference on Entomology (IECE 2021), 1-15 July 2021; Available online: https://iece.sciforum.net/.

\begin{abstract}
Meloidae Gyllenhaal, 1810 (Coleoptera) presents a complex biology, but despite this, after decades there have been no significant advances in the understanding of its ecology or distribution, information on which the most basic conservation tools are based. Also, the discover of pseudocryptic complexes has turned the current situation even more difficult. In this delicate global change scenario, new generation of knowledge is pressing. A literature study has been carried out to summarize for the first time all known impacts. Also, samplings were carried out from 2012 and are still on development, with the help of Citizen Science. At least 32 species are suffering from human impacts, mainly habitat fragmentation due to an aggressive urban development and extensive agriculture with use of pesticides. Concretely for meloids of the Iberian Peninsula, more than $30 \%$ are endemic, many of them threatened: The information is in general, very brief, with 9 species having a greater coverage of information than the rest. Further studies are needed urgently.
\end{abstract}

Keywords: Blister beetle; Change in land uses; Coleoptera; Insect conservation; fragmentation; Global change; Meloidae; Oil-beetle; pesticide

\section{Introduction}

Meloidae Gyllenhaal, 1810 (Coleoptera, Insecta) constitutes an iconic beetle group distributed across all continents -except for Antarctica- represented by more than 2500 species distributed in more than 120 genera [1]. Members of this group have two very remarkable biological characteristics common to all of them.

In the first place, these animals have antipredatory chemical defences. Specifically, they present the monoterpene cantharidin in their hemolymph, which they expel to the outside through autohemorrhage when they feel in danger [2]. Cantharidin is powerful toxin that act as a vesicant on skin contact but also can be lethal in small doses if ingested [2]. This potential danger is indicated by Mullerian mimicry [2,3] in many of the species, usually constituted by red, orange or yellowish colours combined with dark tones such as black, usually represented by dots/stripped patterns in different parts of their morphology.

The second remarkable characteristic, which also concerns us given the nature of this manuscript, is that meloids have a hypermetabolic development, probably the most complex in the animal kingdom, presenting up to eight different stages before reaching imaginal stage, with markedly different morphological changes and lifestyles among them $[2,4]$.

It should also be noted other essential biological points, that also reflect the diversity of these animals in terms of their evolutionary history. In their first instar larvae, they are obligate parasitoids of different groups of insects. Depending on the clade, hosts may 
vary, for example solitary bees (e.g., genera Lampromeloe Reitter, 1911; Meloe Linnaeus, 1758; Megetra LeConte, 1859; Physomeloe Germar, 1818) or grasshoppers (e.g., Epicauta Dejean, 1834; Lytta Fabricius, 1775; Mylabris Fabricius, 1775, Zonitis Fabricius, 1775) [2]. This biological aspect makes them vitally dependent on their host for their proper vital development and survival [2]. There are two large groups- These traits are not monophyletic but conform two major types of life cycle- in terms of how they manage to access the guest. The first of them, the non-phoretic species, the most ancestral -although this trait has later reappeared due to plesiomorphy in more recent clades [1]- present a marcher first instar that actively seeks the nests of solitary bees to eat their reserves and larvae [2]. The second is constituted by those species that present a phoretic larva. First instar detects the host in their adult stage, for example a bee that has landed in a flower, and cling to it to be transported to the nest [2], acting the bee as a Trojan horse.

In addition, meloids could be classified into two large groups in terms of lifestyles, a trait that is not monophyletic either-it has appeared several times in the different clades that make up the family - but helps us to understand the two main environments where they develop their biology. The first of them would be the flying floricultural type [2], with longer dispersions and mobilities in space, and a second, epigean, creeping [2], with massive and apterous morphology. The latter includes large species, such as the genus Berberomeloe Bologna, 1988, which is among the largest beetles in Europe, with sizes that reach up to $7 \mathrm{~cm}[5,6]$ and a limited dispersal capacity [5].

As can be seen, the complexity of the group increases given the amount of different and complex forms of life, from very large and easily observable species to very small, from meloids that feed on flowers and have phoretic larvae, through epigean meloids but that present the same type of larvae, to epigean species with non-phoretic larvae, some of them linked to an obligate parasitoidism with hymenopterans, while others with orthopterans. This scenario presents a handicap for their study and therefore the knowledge about their ecology, that added to the current global change, form an undesirable combination for conservation. It is known that the rate of anthropic transformation in ecosystems is alarming, causing many insects, including meloids, to suffer important impacts that affect their populations [7]. There are already indications that many meloids are suffering population regressions and local extinctions, with diverse species catalogued in red lists from various national and regional governments [8-10].

After decades, apart from taxonomic reviews and molecular biology studies, there have been no significant advances in the understanding of its behavior, ecology and distribution, information on which the most basic conservation tools are based, such as distribution maps or evaluation criteria for threatened species. Specifically, the Iberian Peninsula constitutes a European biodiversity hotspot, presenting a highly diverse entomofauna, also for Meloidae clade. Out of 69 blister beetles present more than $30 \%$ constitutes endemic species exclusive to this region $[11,12]$. Also, and in the same way that has occurred in other regions of the world, the frequent discover new species [13-15], among others] and pseudocryptic complexes [e.g., 12] - considered one of the greatest challenges for current conservation [16]- has turned the issue even more difficult, with new and poorly known erected species.

Therefore, given the clear gaps in existing knowledge, it is necessary to jointly analyze and study the impacts detected so far that are affecting Meloidae populations and carry out a specific study to generate new and necessary ecological information to be able to evaluate the conservation status of these complex insects.

\section{Material and Methods}

\subsection{Literature Study}


A literature study was conducted, consisting in a review to summarize as many impacts as possible to collect for blister-beetle clade, with special emphasis on Iberian species, which are in a situation of special vulnerability, given that there are already diverse endemisms listed in red books, both nationally and regionally. Time range used for the study was complete, from the first reference found to present year 2021. Search was developed on databases Web of Science (Clarivate Anlaytics, hereafter "WOS") and Scopus (Elsevier) using "Meloidae", "Meloidae conservation", and "threatened Meloidae" as search term. Articles were also hand searched in both ResearchGate, Google Scholar, and other sources. Criteria for including references in the study were 1) That they deal specifically with Conservation Ecology of Meloidae or provided relevant information that had to be taken into account.

\subsection{Sampling Campaigns}

On the other hand, sampling campaigns throughout the Iberian Peninsula have been carried out since 2012 - still under development today-to describe, first-hand, some impacts suffered by this clade. The samplings consisted of detecting those areas conducive to meloid species [2] and carrying out samplings of these areas as complete and extensive as possible. Once a population was detected, the species were identified together with the type of environment: "natural" if conserved, "suburban" if they were near to urban nuclei, or "crops" if they were in agroecosystems. Also, possible threats that were affecting said population were characterized. If necessary, they were revisited in successive years.

Also, in a complementary way, "Meloidata" Citizen Science program have been launched, covering the ibero-maghrebian region, with the help of citizens and diverse Citizen Science organizations as Observation.org Spain (https://spain.observation.org/) and BiodiversidadVirtual (www.biodiversidadvirtual.org). In this project, users could participate by sending locations with georeferenced photographs that have subsequently been verified. After filtering observations, participants were inquired to describe the environment where these sightings had been made. Locations of interest were visited to characterize them.

\section{Results}

\subsection{Literature Review}

After a specific search with "conservation Meloidae" as term, only 22 results from WOS and 11 from Scopus were obtained. After the filtering process, only 5 works dealed with a conservationist perspective [17-21]. Third, specific search with "threatened Meloidae" only generated 5 results from WOS and 1 from Scopus. from which 108 duplicate results were eliminated. The largest number of works was found by manual search: 19 references, all of them non-indexed [8-10, 22-36].

In fact, given the scarcity of results, an unforeseen search was carried out, with the name of the family "Meloidae" as a criterion, to observe the general results for the entire taxon in the last decade (2010-2020) and once the references were filtered with the same criteria, the same 4 manuscripts were obtained as in the previous searches. Most of the references were discarded because they dealt with Systematics, Taxonomy, morphological description of new species, the majority of research that has prevailed over the rest in recent times.

In general, extant information was very scarce, outdated in most cases (references with more than 10-20 years). At the moment, there is no IUCN assessment for any species. There is also no legal protection figure for any of them. Main problem is, in view of the results, the scarcity of information available to evaluate these species adequately. At least 
32 species are suffering from human impacts, mainly habitat fragmentation due to an aggressive urban development and extensive agriculture with use of pesticides.

From the total number of references, it should be noted a total of 13 focused on the Iberian Peninsula [8-10,23-33], 11 of them belonging to initiatives carried out by Spanish regional and national governments to elaborate catalogues of theatened species, in the form of evaluation sheets [9,10-24-32]. Redundant information was detected in some manuscripts, due to these 11 references really address 9 different species; since 2 andalusian endemisms, Berberomeloe insignis (Charpentier, 1818) and Mylabris nevadensis (Escalera, 1915) were first evaluated for Andalusian region in 2008 [24,27] and two years later, those works were used as basis for national evaluation forms [28-30]. In Andalusian Red Book, 6 more species were also cited, appearing cataloged as "data deficient" (DD) but without a possible explanation as to why they are believed to be threatened $[9,10]$.

Outside the Iberian Peninsula, it is worth highlighting the initiative "Oil Beetle Hunt" carried out by the British-based nature conservation charity Buglife - The Invertebrate Conservation Trust, in partnership with the National Trust and Oxford University Museum of Natural History, consisting in a species recovery programme, launched in 2009, where a considerable amount of information of interest has been collected thanks tou the use of Citizen Science, such as distribution maps to observe population trends throughout the years [35].

Most threats covered on literature are related to changes in habitat due to degradation, aggressive urban planning, and inappropriate or aggressive agricultural practices. On the other hand, it is worth highlighting the use of biocides and the loss of hosts that parasitize these species. A summary of anthropic impacts identified cited as possible problems for the conservation of meloids can be consulted in Appendix A, divided by species and reference. The scientific name of the species has been updated based on the most recent systematic and phylogenetic studies.

In general, all species enlisted suffer from data deficience, as can be consulted in references of Table A1. It is also of interest that most of the listed species are epigean species without flight capacity. It seems that species of the same genus share similar threats, which have a clear coherence in biological and phylogenetic terms. Many of them are endemisms with a very restricted distribution, as is the case of Berberomeloe insignis from the southeast of Spain or Mylabris nevadensis from Sierra nevada, Granada.

\subsection{Field work and Citizen Science Program}

A total of 271 samplings were carried out. 800 individuals from 60 different locations were studied. Regions sampled for the moment are Albacete, Ávila, Cádiz, Ciudad Real, Málaga, and Madrid (Figure 1).

Clear signs of transformation were identified in at least 20 populations, most of them constituted by epigean blister-beetle species. List of potential impacts identified has been collected in Table 2. Concretely, 18 affected nuclei were located along suburban environments and on three different Iberian endemisms, Berberomeloe castuo SánchezVialas et al., 2020, B. payoyo Sánchez-Vialas et al., 2020 and Physomeloe corallifer Germar, 1818. Throughout the development of this research, 2 of them presumably suffered a local extinction, but further data are needed. Also, citizen science program provided 5 additional locations, of which 2 presented some type of threat to their conservation. 


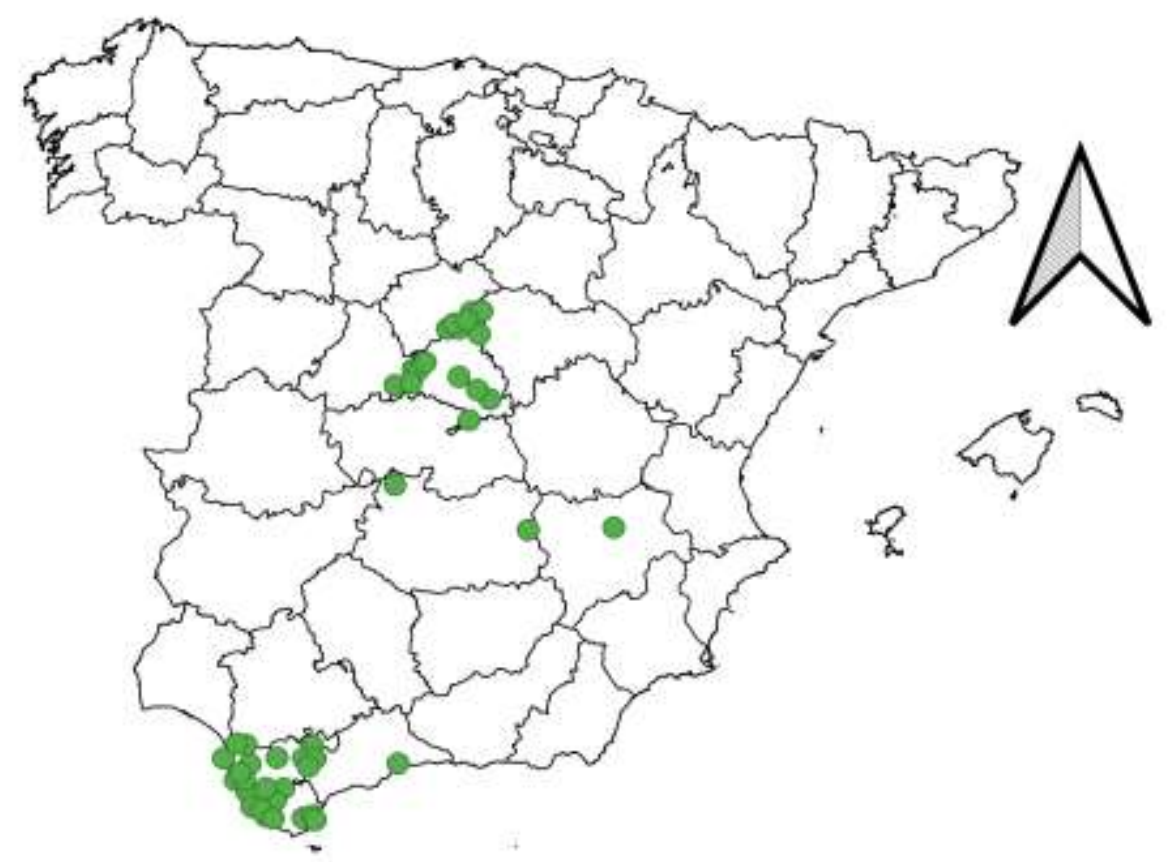

Figure 1. Point cloud of the sampled regions in the Iberian Peninsula as of July 2021, generated with QGIS 3.16.1 Hannover using the layer "Líneas límite provinciales" from Instituto Geográfico Nacional (centrodedescargas.cnig.es). 271 samplings in total have been carried out in 60 different locations within the areas indicated on the map.

Most of impacts are related to two main aspects. The first is the transformation of the environment, highlighting urban development, fragmentation and changes in land use. The second is related to direct impacts on the species, such as the use of biocides, deaths from road traffic collisions or by human transit.

Table 2. Potential impacts identified classified by species and environment type, natural if conserved, suburban if location is near urban nuclei, and crop field if population was observed within agroecosystems.

\begin{tabular}{ccc}
\hline Species affected & Impact & Environment type \\
\hline Berberomeloe payoyo & Illegal dumping & Natural/suburban \\
Berberomeloe payoyo & Fragmentation & Suburban \\
Berberomeloe payoyo & Quarrying & Suburban \\
Berberomeloe payoyo & Phytosanitary treat. & Crops \\
Berberomeloe payoyo & Road traffic & Natural/suburban \\
Berberomeloe payoyo & Soil overexploitation & Crops \\
Berberomeloe payoyo & Urban development & Natural/suburban \\
Berberomeloe cf. comunero & Fragmentation & Natural/suburban \\
Berberomeloe cf. majalis & Human transit & Natural \\
Hycleus sp. & Fragmentation & Natural \\
Mylabris sp. & Illegal dumping & Natural \\
Meloe tuccia & Fragmentation & Natural/suburban \\
Physomeloe corallifer & Human transit & Natural \\
Physomeloe corallifer & Urban development & Natural/suburban \\
\hline
\end{tabular}

\section{Discussion}


The family Meloidae present a very complex development and, in a context of global change, is facing great challenges. Conservation of the group is a fairly unexplored field, as we lack much relevant and necessary information for the environmental evaluation and management of species if necessary. Advances are mainly centered on phylogenetic relationships, as well as evolutionary origins. New species are described very frequently, a fact that illustrates their richness. However, this seems to go hand in hand with a greater lack of ecological information as the number of species described rises.

In the last decade there were no substantial advances in the knowledge of meloid conservation. Very few studies have dealt with this matter adequately and in depth, and there are very important information gaps that must be urgently covered. It is relevant to note that, to date, in Spain there is no reliable or recent distribution maps for any species of meloid, not even for Iberian endemisms with a very restricted distribution. In fact, few ex profeso studies have been performed to know the distribution of any of the Iberian species. For example, for Berberomeloe insignis, a south-eastern Iberian endemism, whose total distribution is predictably small and can be covered relatively easily, specific sampling campaigns have been carried to approach this issue. This is, probably, the only species that for the moment has come closest to a conservation evaluation, being included in the Red Book of Threatened Invertebrates of Andalusia [9]and its corresponding homonym at the Spanish level [10]. However, there are no new studies published in the last ten years outside of the initiative that these governments carried out in the late 2000s. There are also no follow-up studies with periodic resampling in the region, in order to detect possible new grids in the UTM 10x10 distribution maps, in order to have a document as complete and up-to-date as possible, given that the area where this species distributes also has a very high degree of human transformation. even knowing that the most impacted populations of the species were in great difficulty to survive, and the most conserved seemed to present viability in the short-medium term [28]. In fact, and despite clear signs about the need to collect data, that can allow to carry out assessments according to the IUCN criteria, at the moment neither B. insignis nor any other blister-beetle has been evaluated or included in the IUCN Red List of Threatened Species.

With respect to threats that Meloidae communities are currently suffering, it can be stated by gathering all results obtained that, probably, the main anthropogenic modification is related to changes in land use, including habitat loss urban development, that are causing important impacts on insect communities. In this case, impacts seem to be more appreciable in non-phoretic epigean species, maybe given their low dispersal capacity. On the other hand, there are documented cases of meloid populations and species that have already suffered local and even regional extinctions.

Despite their diversity, whole clade present similar traits in their life cycle, so is highly probable that the impacts presented, are spreadable to the rest, as many works have already suggested.

\section{Conclusions}

In general, ecological studies in the family Meloidae must be addressed urgently. The biggest problem to solve is the lack of basic and crucial information for the evaluation and conservation of its diversity, knowledge is for the moment incomplete, obsolete or has not yet been generated, even though there are documented cases of impacts including endemic species whose distribution is very restricted and have a real risk of extinction. Therefore, in this scenario of accelerated anthropogenic change, it is essential to address this issue as soon as possible. Although the rest of the disciplines are crucial, concretely it is necessary to carry out detailed and in-depth studies of conservation ecology on these complex beetles. Due to the lack of reliable data that allow an in-depth knowledge, both the scientific community and the administrations that could implement tools and solid legal frameworks, cannot advance in the conservation of this entomofaunal wealth, while 
it is a duty pressing against the clear regressions of populations and local, regional, and even national extinctions that these insects are suffering.

Funding: This research received no external funding

Institutional Review Board Statement: Not applicable.

Informed Consent Statement: Not applicable.

Data Availability Statement: Not applicable.

Acknowledgments: Thanks to all villagers and citizen scientists that kindly contributed to this work over the years by providing locations and records. Special thanks to Irene Martín-Rodríguez, Juan Manuel Muñoz-Ocaña, Fernando Cortés Márquez for field supporting. Also, thanks to professors Marco Bologna and Juan Lucas Cervera Currado for their advice and valuable feedback over the years.

Conflicts of Interest: Author declare no conflict of interest. 


\section{Appendix A}

Table A1. Impacts cited in the literatures study classified by species and reference. Scientific name of the species has been updated based on the most recent systematic and phylogenetic studies.

\begin{tabular}{|c|c|}
\hline Impact & Species \\
\hline \multirow{7}{*}{ Biocides (direct to species) } & Berberomeloe insignis $[29,28]$ \\
\hline & Berberomeloe payoyo [33] \\
\hline & Eurymeloe nanus [25] \\
\hline & Meloini tribe [29] \\
\hline & Physomeloe corallifer [8] \\
\hline & Lampromeloe variegatus [29] \\
\hline & Taphromeloe foveolaus [26] \\
\hline Forest fires & Taphromeloe foveolaus [26] \\
\hline \multirow{8}{*}{ Fragmentation } & Apalus bimaculatus $[19,34]$ \\
\hline & Berberomeloe insignis $[29,28]$ \\
\hline & Berberomeloe payoyo [33] \\
\hline & Eurymeloe brevicollis [35] \\
\hline & Eurymeloe rugosus [35] \\
\hline & Lampromeloe variegatus [29] \\
\hline & Meloe proscarabaeus [35] \\
\hline & Meloe violaceus [35] \\
\hline Genetic impoverishment & Gnathium minimum [20] \\
\hline Global warming & Mylabris nevadensis $[27,30]$ \\
\hline \multirow{14}{*}{ Habitat loss/degradation } & Apalus bimaculatus $[19,34]$ \\
\hline & Epicauta pensylvanica [21] \\
\hline & Eurymeloe brevicollis [35] \\
\hline & Eurymeloe nanus [25] \\
\hline & Eurymeloe rugosus [35] \\
\hline & Meloe proscarabaeus [35] \\
\hline & Meloe scabriusculus [18] \\
\hline & Meloe uralensis [18] \\
\hline & Meloini/Meloinae [35] \\
\hline & Micromeloe decorus [18] \\
\hline & Meloe violaceus [35] \\
\hline & Mylabris nevadensis $[26,29]$ \\
\hline & Sitaris rufipennis [9] \\
\hline & Taphromeloe foveolaus [31] \\
\hline \multirow{10}{*}{ Host loss } & Apalus bimaculatus $[19,34]$ \\
\hline & Eurymeloe brevicollis [35] \\
\hline & Meloini/Meloinae $[29,35]$ \\
\hline & Eurymeloe brevicollis [35] \\
\hline & Eurymeloe nanus [25] \\
\hline & Eurymeloe rugosus [35] \\
\hline & Hycleus uhagonii [8] \\
\hline & Meloe proscarabaeus [35] \\
\hline & Meloe violaceus [35] \\
\hline & Sitaris rufipennis [9] \\
\hline Illegal dumping & Berberomeloe payoyo [33] \\
\hline \multirow{3}{*}{$\begin{array}{l}\text { Inadequate forestry practices/ unnecessary } \\
\text { reforestation }\end{array}$} & Berberomeloe insignis $[29,28]$ \\
\hline & Eurymeloe nanus [25] \\
\hline & Mylabris nevadensis $[27,30]$ \\
\hline
\end{tabular}




\begin{tabular}{|c|c|}
\hline & Taphromeloe foveolaus [26] \\
\hline \multirow{4}{*}{$\begin{array}{c}\text { Intensive agriculture/ damages derivated } \\
\text { from agriculture }\end{array}$} & Berberomeloe insignis $[29,28]$ \\
\hline & Eurymeloe nanus [25] \\
\hline & Lampromeloe variegatus [29] \\
\hline & Taphromeloe foveolaus [26] \\
\hline Livestock overexploitation & Mylabris nevadensis $[27,30]$ \\
\hline \multirow{2}{*}{ Open-pit mining/ Quarrying } & Berberomeloe insignis $[29,28]$ \\
\hline & Eurymeloe nanus [25] \\
\hline \multirow{4}{*}{ Road traffic } & Berberomeloe payoyo [33] \\
\hline & Berberomeloe sp. [8] \\
\hline & Lampromeloe variegatus [29] \\
\hline & Taphromeloe foveolaus [26] \\
\hline \multirow{9}{*}{$\begin{array}{c}\text { Soil composition changes/ Change in land } \\
\text { uses }\end{array}$} & Berberomeloe insignis $[29,28]$ \\
\hline & Berberomeloe payoyo [33] \\
\hline & Eurymeloe brevicollis [35] \\
\hline & Eurymeloe rugosus [35] \\
\hline & Meloe proscarabaeus $[18,35]$ \\
\hline & Meloe scabriusculus [18] \\
\hline & Meloe uralensis [18] \\
\hline & Meloe violaceus [35] \\
\hline & Micromeloe decorus [18] \\
\hline
\end{tabular}

\begin{tabular}{|c|c|}
\hline Water reserve overexploitation & Berberomeloe insignis $[29,28]$ \\
\hline \multirow{2}{*}{ Unsustainable tourism } & Mylabris nevadensis $[27,30]$ \\
\hline & Taphromeloe foveolaus [26] \\
\hline \multirow{9}{*}{ Urban development } & Berberomeloe insignis $[29,28]$ \\
\hline & Berberomeloe payoyo [33] \\
\hline & Berberomeloe sp. [8] \\
\hline & Eurymeloe nanus [8] \\
\hline & Eurymeloe tuccia [8] \\
\hline & Lampromeloe variegatus [29] \\
\hline & Meloini tribe [29] \\
\hline & Physomeloe corallifer [8] \\
\hline & Taphromeloe foveolaus [26] \\
\hline \multirow{19}{*}{$\begin{array}{l}\text { Unknown reasons but: observed regres- } \\
\text { sion/ supposed to be endangered/extinct } \\
\text { in some region }\end{array}$} & Eurymeloe brevicollis [8] \\
\hline & Eurymeloe mediterraneus [8] \\
\hline & Euzonitis quadrimaculata [8] \\
\hline & Hycleus duodecimpuctatus [8] \\
\hline & Lampromeloe cavensis [8] \\
\hline & Lampromeloe variegatus $[8,29,35,36]$ \\
\hline & Meloe proscarabaeus [8] \\
\hline & Meloe violaceus [8] \\
\hline & Meloegonius cicatricosus [35] \\
\hline & Mylabris amorii [28] \\
\hline & Mylabris deferreri [28] \\
\hline & Mylabris dejeani [8] \\
\hline & Mylabris quadripunctata [8] \\
\hline & Mylabris uhagonii [32] \\
\hline & Mylabris variabilis [8] \\
\hline & Sitaris rufipenis [9] \\
\hline & Sitarobrachys thoracica [9] \\
\hline & Treiodus ajax [22] \\
\hline & Treiodus autumnalis [35] \\
\hline
\end{tabular}




\section{References}

1. Bologna, M.A.; Pinto, J.D. Phylogenetic studies of Meloidae (Coleoptera), with emphasis on the evolution of phoresy. Syst. Entomol. 2001, 26, 33-72. https://doi.org/10.1046/j.1365-3113.2001.00132.x

2. Bologna, M.A.; Fauna de Italia. XXVIII. Coleoptera Meloidae. Edizioni Calderini: Bologna, Italy, 1991; 541 pp

3. Bologna, M.A; Nuove osservazioni sui predatori dei Meloidae (Coleoptera). Boll Ass Romana Entomol. 1983, 38, 63-34.

4. Bologna, M.A.; Oliverio, M.; Pitzalis, M.; Mariottini, P. Phylogeny and evolutionary history of the blister beetles (Coleoptera, Meloidae). Mol. Phylogenet. Evol. 2008, 48(2), 679-693. https://doi.org/10.1016/j.ympev.2008.04.019

5. García-París, M. Revisión sistemática del género Berberomeloe Bologna, 1988 (Coleoptera, Meloidae) y diagnosis de un endemismo ibérico olvidado. Graellsia 1998, 54, 97-109. Available online: http://graellsia.revistas.csic.es/index.php/graellsia/article/view/347 (accesed on 1806 2021).

6. Bologna, M.A. Berberomeloe, a new west Mediterranean genus of Lyttini for Meloe majalis Lineé (Coleoptera, Meloidae). Systematics and bionomics. Ital. J. Zool. 1988, 55(1-4), 359-366. https://doi.org/10.1080/11250008809386633

7. Schachat, S.R.; Labandeira, C.C. Are insects heading toward their first mass extinction? Distinguishing turnover from crises in their fossil record. Ann. Entomol. Soc. Am. 2021, 114(2), 99-118. https://doi.org/10.1093/aesa/saaa042

8. García-París, M.; Trotta-Moreu N.; Capote L. Estado de conocimiento actual y problemas de conservación de los Meloidae (Coleoptera) de la Comunidad de Madrid. Graellsia 2006, 62, 333-370.

9. Barea-Azcón, J.M.; Ballesteros-Duperón, E.; Moreno, D., Eds. Libro Rojo de los Invertebrados de Andalucía. 4 Volumes. Consejería de Medio Ambiente. Junta de Andalucía: Sevilla., Spain, 2008; 1438 pp.

10. Verdú, J.R.; Numa, C.; Galante, E., Eds. Atlas y Libro Rojo de los Invertebrados amenazados de España (Especies Vulnerables) Vol I. Dirección General de Medio Natural y Política Forestal, Ministerio de Medio Ambiente, Medio rural y Marino. Madrid, Spain, $2011 ; 719$ pp.

11. García París, M. Familia Meloidae. In: IBERFAUNA. El Banco de Datos de la Fauna Ibérica.; Museo Nacional de Ciencias Naturales (CSIC): Madrid, Spain, 2017. Digital. Available online: $\underline{\text { http://iberfauna.mncn.csic.es/showficha.aspx? } \mathrm{rank}=I \& i d t a x=3617}$ (accesed on 1806 2021).

12. Sánchez-Vialas, A.; García-París, M.; Ruiz, J. L.; Recuero, E. Patterns of morphological diversification in giant Berberomeloe blister beetles (Coleoptera: Meloidae) reveal an unexpected taxonomic diversity concordant with mtDNA phylogenetic structure. Zool. J. Linn. Soc., 2020, 189(4), 1249-1312. https://doi.org/10.1093/zoolinnean/zlz164

13. Bologna, M.A.; Cerny, L.; Zubair, A. Meloidae (Coleoptera) of Pakistan and Kashmir with the description of three new species, new faunistic and taxonomic records, and a zoogeographic analysis. Turk. Zool. Derg. 2018, 42(6), 637-660. https://doi.org/10.3906/zoo-1712-36

14. Černý, L.; Bologna, M.A. (2018). A new species of Diaphorocera from Morocco with unclear relationships and a key to the species (Coleoptera, Meloidae, Cerocomini). ZooKeys 2018, (748), 57-64. https://doi.org/10.3897/zookeys.748.22176

15. Li, X.; Li, J.; Pan, Z. New species and new faunistic records of the family Meloidae Gyllenhal, 1810 (Coleoptera: Tenebrionoidea) from China, with a list of meloid species from Xinjiang. J. Asia. Pac. Entomol. 2020, 23(4), 1144-1150. https://doi.org/10.1016/j.aspen.2020.09.006

16. Bickford, D.; Lohman, D.; Sodhi, N.; Ng, P.; Meier, R.; Winker, K.; Ingram, K. Cryptic species as a window on diversity and conservation. Trends Ecol. Evol. 2007, 22 (3), 148-55. https://doi.org/10.1016/j.tree.2006.11.004

17. Kerr, J.T.; Packer, L. The environmental basis of North American species richness patterns among Epicauta (Coleoptera: Meloidae). Biodivers. Conserv., 1999, 8(5), 617-628. https://doi.org/10.1023/A:1008846131749

18. Cizek, L.; Hauck, D.; Pokluda, P. Contrasting needs of grassland dwellers: habitat preferences of endangered steppe beetles (Coleoptera). J. Insect Conserv. 2012, 16(2), 281-293. https://doi.org/10.1007/s10841-011-9415-6

19. Ahlbäck, L.; Berggren, $\AA$. The effect of landscape structure and habitat composition on the presence of the threatened parasitic sand-living beetle Apalus bimaculatus (Coleoptera: Meloidae). Can. Entomol. 2012, 145(6), 626-638. https://doi.org/10.4039/tce.2013.43

20. Marschalek, D.A.; Berres, M. E. Genetic population structure of the blister beetle, Gnathium minimum: Core and peripheral populations. J. Hered. 2014, 105(6), 878-886. https://doi.org/10.1093/jhered/esu053

21. Marschalek, D.A.; Ogden, H.V.; Wolcott, D.M. A Marking Study of the Black Blister Beetle, Epicauta pensylvanica (Degeer) (Coleoptera: Meloidae), Demonstrates a Preference for a Restored Tallgrass Prairie. J. Kans. Entomol. Soc. 2020, 92(4), 639-648. https://doi.org/10.2317/0022-8567-92.4.639

22. Pinto, J.D. A New Meloe Linnaeus (Coleoptera: Meloidae, Meloinae) from Southern California Chaparral: A Rare and Endangered Blister Beetle or Simply Secretive? Coleopt. Bull. 1998, 52 (4), 378-385. Available online: www.jstor.org/stable/4009345 (accesed on 1806 2021).

23. Moreno, I.P.; Moreno, A.F.S.M.; Irurzun, J.I.R. Aportaciones corológicas y faunísticas sobre meloidos ibérico (Coleoptera: Meloidae). Bol. SEA 2003, 33, 195-217.

24. García-París, M.; Ruíz, J.L. Berberomeloe insignis (Charpentier, 1818). In: Libro Rojo de los Invertebrados de Andalucía; Barea-Azcón, J.M., Ballesteros-Duperón, E., Moreno, D., Eds.; Volume 3. Consejería de Medio Ambiente. Junta de Andalucía: Sevilla, Spain, 2008; pp. 1020-1029. 
25. Ruíz, J.L.; García-París, M. Meloe (Eurymeloe) nanus Lucas, 1849. In: Libro Rojo de los Invertebrados de Andalucía; Barea-Azcón, J.M., Ballesteros-Duperón, E., Moreno, D., Eds.; Volume 3. Consejería de Medio Ambiente. Junta de Andalucía: Sevilla, Spain, 2008; pp. 1030-1037.

26. Ruíz, J.L.; García-París, M. Meloe (Taphromeloe) foveolatus Guérin de Méneville, 1842. In: Libro Rojo de los Invertebrados de Andalucía; Barea-Azcón, J.M., Ballesteros-Duperón, E., Moreno, D., Eds.; Volume 3. Consejería de Medio Ambiente. Junta de Andalucía: Sevilla, Spain, 2008; pp. 1038-1044.

27. García-París, M.; Ruíz, J.L. Mylabris (Micrabris) nevadensis (Escalera, 1915). In: Libro Rojo de los Invertebrados de Andalucía; BareaAzcón, J.M., Ballesteros-Duperón, E., Moreno, D., Eds.; Volume 3. Consejería de Medio Ambiente. Junta de Andalucía: Sevilla, Spain, 2008; pp. 1045-1051.

28. García-París, M.; Ruíz, J.L. Berberomeloe insignis (Charpentier, 1818). In: Atlas y Libro Rojo de los Invertebrados amenazados de España (Especies Vulnerables); Verdú, J.R., Numa, C., Galante, E., Eds.; Volume I. Dirección General de Medio Natural y Política Forestal, Ministerio de Medio Ambiente, Medio Rural y Marino: Madrid, Spain, 2011; pp. 285-294.

29. García-París, M.; Ruíz, J.L. Meloe (Lampromeloe) variegatus Donovan, 1793. In: Atlas y Libro Rojo de los Invertebrados amenazados de España (Especies Vulnerables); Verdú, J.R., Numa, C., Galante, E., Eds.; Volume I. Dirección General de Medio Natural y Política Forestal, Ministerio de Medio Ambiente, Medio Rural y Marino: Madrid, Spain, 2011; pp. 295-302

30. García-París, M.; Ruíz, J.L. Mylabris (Micrabris) nevadensis (Escalera, 1915). In: Atlas y Libro Rojo de los Invertebrados amenazados de España (Especies Vulnerables); Verdú, J.R., Numa, C., Galante, E., Eds.; Volume I. Dirección General de Medio Natural y Política Forestal, Ministerio de Medio Ambiente, Medio Rural y Marino: Madrid, Spain, 2011; pp. 303-308

31. García-París, M.; Ruíz, J.L. Meloe (Taphromeloe) foveolatus Guérin de Méneville, 1842. In: Atlas y Libro Rojo de los Invertebrados amenazados de España (Especies en Peligro Crítico y en Peligro); Verdú, J.R, Galante, E., Eds. Dirección General de Medio Natural y Política Forestal, Ministerio de Medio Ambiente, Medio Rural y Marino: Madrid, Spain, 2009; pp. 121-124

32. García-París, M.; Ruíz, J.L. Mylabris uhagonii Martínez y Sáez, 1873. In: Atlas y Libro Rojo de los Invertebrados amenazados de España (Especies en Peligro Crítico y en Peligro); Verdú, J.R, Galante, E., Eds. Dirección General de Medio Natural y Política Forestal, Ministerio de Medio Ambiente, Medio Rural y Marino: Madrid, Spain, 2009; pp. 125-129.

33. Cortés-Fossati, F. Un primer acercamiento al estado de conservación de las poblaciones de Berberomeloe majalis (Linnaeus, 1758) (Coleoptera: Meloidae) en la provincia de Cádiz (España). Observaciones de campo y percepciones del mundo rural sobre el estado de la especie. Bol. SEA, 2018, 62, 327-331.

34. Ahlbäck, L.; Sallmén, N.; Hedin, Å.; Berggren, Å. Translocation of a sand-associated blister beetle due to urban development in Uppsala, Sweden. In: Global Reintroduction Perspectives: 2018. Case studies from around the globe; Soorae, P.S., Ed.; IUCN/SSC Reintroduction Specialist Group, Gland, Switzerland and Environment Agency: Abu Dhabi, 2018; pp 1-6. https://doi.org/10.2305/IUCN.CH.2018.08.e

35. BugLife - The Invertebrate Conservation Trust. Oil Beetle Hunt. Available online: https://www.buglife.org.uk/get-involved/surveys/oil-beetle-hunt/ (accesed on 1806 2021).

36. UK Oil Beetle Recording. Oil Beetle Scheme. Available online: Oil Beetle Recording Scheme | UK Beetle Recording (coleoptera.org.uk) (accesed on 1806 2021). 